\title{
The European Union's idea of gender equality and its support among citizens of 27 European countries.
}

Jürgen Gerhards, Sylvia Kämpfer \& Mike S. Schäfer

Berliner Studien zur Soziologie Europas

Nr. 10

Januar 2008

Freie Universität Berlin, Institut für Soziologie, Garystraße 55, D-14195 Berlin 
Die „Berliner Studien zur Soziologie Europas“ des Lehrstuhls für Makrosoziologie der Freien Universität Berlin verstehen sich als ein Ort zur Vorpublikation von Beiträgen, die später in Fachzeitschriften und Sammelbänden veröffentlicht werden sollen. Die Beiträge sollen helfen, eine Soziologie Europas zu profilieren; sie stehen auch im Kontext des Master-Studiengangs „Soziologie - Europäische Gesellschaften“.

Gegenstand der Reihe sind Beiträge zur Analyse der Herausbildung einer europäischen Gesellschaftsstruktur und -kultur, vergleichende Analysen, die die Unterschiede und Gemeinsamkeiten zwischen verschiedenen europäischen Gesellschaften thematisieren, sowie theoretische Versuche einer Soziologie Europas.

Ziel der Reihe ist es, durch die frühe Verbreitung dieser Arbeiten den wissenschaftlichen Gedankenaustausch zu fördern. Die Beiträge sind nur über das Internet als pdf-Datei zu beziehen.

Zitationsweise: BSSE-Arbeitspapier Nr. 10. Berlin: Freie Universität Berlin.

Dieser Artikel erscheint in „Sociology“. 


\begin{abstract}
This article first describes the European Union's idea of gender equality and its implementation into European policies. The second section analyses the extent to which citizens of different European countries support the idea of gender equality. The empirical basis for our analysis is the "Eurobarometer 63.1" from 2005. The descriptive findings show that while a majority of European citizens support the idea of gender equality, there are substantial differences between individual countries. In the third section we explain these differences by referring to the country's level of modernization and degree of politically institutionalised gender equality, as well as the respondents' religious orientation and level of education, among other factors.
\end{abstract}


Over the last several decades in many countries the relationship between women and men has been the focus of intense societal debates, which resulted in tremendous political and societal change. ${ }^{1}$ To some extent these changes are explained in the literature by endogenous factors of the respective countries, such as the strength of domestic women's movements or national culture (cf., e.g., Daley/Nolan 1994). However, the global reach of these processes led neo-institutionalist theorists to interpret them as the results of a world polity-a cultural model spread by international institutions and supranational organizations (Ramirez et al. 1997, see also Meyer et al. 1997, Wobbe/Biermann 2007).

The European Union (EU) is one such supranational organization, and certainly one of the largest and most influential. Since its early days in the 1950s, the EU has expanded dramatically. After its recent Southeastern enlargements in 2004 and 2007, it now consists of 27 member states with almost 500 million citizens. The EU began as an economic union, but has become active in an increasing number of other policy fields over time (Wessels 1997). The political aim of the EU is not only to economically integrate the member states, but also to further cultural similarities between the countries. Taking up considerations from neo-institutionalist theory, we have elsewhere interpreted the EU as a "value entrepreneur" that has developed definite ideas of how European society should look. These conceptions of the ideal European society extend far beyond the economic realm; in pursuing its goal of creating a single European society, central EU institutions are intervening increasingly into the member states' national structures. We have described in other works how the EU defines this unified European society in terms of different value spheres, such as religion, economy, family, environmental protection, democracy, and civil society (Gerhards/Hölscher 2003, Gerhards/Hölscher 2005, Gerhards 2007, Gerhards/Lengfeld 2006, Hölscher 2006). This article ties in to our overall analysis.

The EU has also developed ideas about gender relations (Wobbe 2001). In the first section of the article, we reconstruct how the principle of equality between women and men is anchored in EU legislation. The second section of the article analyses the extent to which citizens support the idea of gender equality and whether there are differences among EU member states. The empirical basis used to reconstruct the citizens' value orientations is a secondary analysis of the "Eurobarometer 63.1", a representative survey conducted in the 27 EU member states and in Turkey. Citizens' acceptance and support of EU regulations is significant, especially in terms of the legitimacy of EU policies. This is due to the fact that democracies are structurally de-

1 We would like to thank Silke Hans for helpful comments and Joanna Schenke for her revision of the translation. 
pendent on the support of their citizens (Page/Shapiro 1983). If this support is lacking, legitimacy problems may arise for the institutions themselves. ${ }^{2}$

The findings show that a majority of European citizens support the idea that women and men should enjoy the same rights and opportunities, but also show substantial differences between countries and individuals. EU enlargement has changed the community's overall level of support for gender equality; however, values are not immutable, and change depends on the social conditions that mould these attitudes. It is therefore important to analyse which social contexts influence personal beliefs concerning gender equality. In the third section, we ask how these differences might be explained. We formulate several hypotheses that are then tested with a multilevel analysis. Results are summarized and discussed in the final section.

\section{The European Union's idea of equality between women and men}

We use official EU documents to construct an EU blueprint of gender relations. ${ }^{3}$ We include primary law, such as founding or supplementary treaties as well as secondary law, which includes EU regulations, directives, and decisions. These documents are legally binding for the member states and therefore called "hard law". We additionally include "soft law," such as Commission recommendations, Commission communications, Council opinions, Council resolutions, or Commission action plans. These documents are not legally binding, but often contain EU goals. This broad approach seems necessary as gender equality has been addressed by the EU in both hard and soft law. However, we concentrate on hard law for our reconstruction wherever possible, as those documents are of higher importance within the EU and implemented to a higher degree in the member states.

The EU's general goal is equality and non-discrimination between women and men, which it perceives as a "priority task of the Union" (European Commission 2006a: 3). This goal is mirrored in several crucial legislative documents: Article 2 of the Maastricht Treaty (signed in 1992) obliges the EU "to promote throughout the Community a harmonious, balanced and sustainable development of economic activities, a high level of employment and of social protection, equality between men and women, sustainable and non-inflationary growth, a high degree of competitiveness and convergence of economic performance, a high level of protection and improve-

2 One example of this legitimacy deficit was the May 2005 French and Dutch rejection of the European Constitution; the elite project of giving Europe a new constitution failed after citizens of two member states refused to support the idea.

3 It must be noted that EU law constitutes ideal models that the EU wants to further, i.e., goals and values that are not necessarily-and, in fact, often not-realized. Nevertheless, they are of crucial importance as they are often used by the EU to benchmark developments in member countries and to decide on membership for candidate countries such as Turkey. 
ment, of the quality of the environment, the raising of the standard of living and quality of life, and economic and social cohesion and solidarity among Member States." (European Commission 2006a: 15) The EU's Charter of Fundamental Rights (European Union 2000) states that "[a]ny discrimination based on any grounds such as sex ... shall be prohibited" (Chapter III, Art. 21) and that "[e]quality between men and women must be ensured in all areas" (Chapter III, Art. 23). Similar formulations can be found in the newly signed Treaty of Lisbon (European Union 2007: e.g. Art. 1a, 2).

The goals formulated in these documents remain somewhat abstract and are not directly effective in the member states (Schmidt 2005: 51). When focusing on more concrete EU regulations, it becomes obvious that gender questions in the EU-in accordance with the EU's history as an economic community-pertain mostly to economic matters (cf. Schmidt 2005: 40, Schunter-Kleemann 1992). Most EU regulation regarding gender relates to the economy, particularly to equality in the workplace (Bergmann 1999, Ostner 1992, Watson 2000). ${ }^{4}$ The principle of gender equality in the workplace has a long tradition in the EU, going back to the Treaties of Rome (signed in 1957), which stated that "men and women should receive equal pay for equal work" (European Union 1957: Article 119). Subsequent EU directives also emphasized the importance of equal payment (1975) and treatment (1976) of both genders at the workplace as well as issues such as social security $(1978,1986)$ and maternity leave (1992) (cf. Schmidt 2005: 42ff). The Treaty of Amsterdam (1997) adopted and expanded this concept in Article 141, and numerous regulations and community directives have since supplemented this article. Decisions substantiated by the European Court of Justice provided a legal anchor for gender equality (Bergmann 1999: 45ff., Wobbe 2001). One such example is a court decision on equal employment opportunities for women in the German army. The plaintiff won the right to be employed in the German army, which precipitated a change in the German constitution (Wobbe 2001). The principle of gender equality includes equal treatment for men and women in a number of areas, such as access to employment, job counselling, education, work conditions, and also membership in employee and employer organizations. Member states have by and large adopted these EU directives into their national legislations.

Both political actors and academic scholars, however, have criticized the EU's rather narrow, workplace oriented approach towards gender equality. To them, it seems especially problematic that household chores, mainly performed by women, do not count as employment; access to employment is therefore perceived to be structurally unequal (Ostner 1992). The EU responded by trying to make employment more compatible with housework by calling for improvements in childcare and

4 This does not mean that substantive gender equality has been achieved in work places around Europe. Kristin Bergmann (1999) provides evidence of enormous differences between EU member states despite the legal adoption of this provision. 
by encouraging that household chores be more equitably divided between men and women (European Commission 1994: 47).

The EU also began to extend the principle of gender equality to other spheres (cf. Wobbe/Biermann 2007), which intensified after the Treaty of Amsterdam in 1997 (cf. Schmidt 2005: 43). In the political sphere, the EU intended to widen the participation of women, particularly in central, decision-making positions (e.g. European Commission 2000). Article 3 of the Treaty of Amsterdam generally obliged the European Commission to facilitate gender equality in all policy spheres (Läufer 1999). At the March 2000 meeting in Lisbon, European heads of state further substantiated this type of equality for political-employment measures, and the Commission decided "to commit itself formally to gender balance in all expert groups and committees" (Schmidt 2005: 44). Furthermore, with the implementation of Gender Mainstreaming by the European Commission, the principle of gender equality became generally applicable to all EU policy areas (Schmidt 2005: 29ff).

A second sphere in which gender equality was targeted, although somewhat less pronounced, is education. The Council of the European Union finalized non-binding resolutions and action programs to create "equal opportunities for girls and boys in education" (1985) as well as to further the participation of women in science (2001) and in the knowledge society in general (2003).

This wider understanding of gender equality-which extends beyond the workplace to include political participation and education-was extended comprehensively in EC recommendations and in three well-funded "Positive Action Programs" that occurred between 1988 and 2001 (e.g. Schmidt 2005: 46). Furthermore, the implementation of gender equality in the wider sense-and with specific attention to political decision-making and education-will remain a central political goal for the EU, as stated in the 2006 to 2010 EU "Roadmap" for gender equality (European Commission 2006b).

Despite this action, certain aspects of gender relations are beyond the realm of EU politics, most notably family matters such as the division of labour in the household. With the exception of domestic violence and other forms of criminal action, family matters are still seen as private and/or national matters to be dealt with in national legislation (Ostner/Lewis 1998: 218f).

In sum, it has become clear that EU policy on gender relations focuses primarily on equality. This equality is an overarching political goal that is not generally restricted to particular societal spheres and can be found in primary, secondary, and tertiary or "soft" law. Most EU documents have perceived gender equality in the workplace and in the economic realm to be the most important issue. The EU's approach towards gender equality has, however, broadened in recent years to include the participation of women in decision-making and political positions, and to a lesser degree in education and science. In our subsequent comparison of citizens' attitudes 
towards gender equality, we will therefore focus on these three aspects of gender relations.

\section{Attitudes of EU citizens towards gender equality}

This analysis of EU citizens' attitudes towards gender equality is based on a secondary analysis of the "Eurobarometer 63.1", a survey that includes several questions concerning the relationship between women and men. Fieldwork for the survey took place in January and February 2005, and a total of 31,390 participants in 34 countries $^{5}$ were questioned. All 27 current EU member states, several candidate countries such as Turkey, and non-member countries like Switzerland or Iceland were surveyed. Country samples contain between 504 and 1,241 participants and are representative for the respective countries.

In our analysis, we aimed to operationalize EU policy on gender relations with concrete survey questions. As outlined above, the EU emphasizes equality between women and men, with particular emphasis on the economic sphere, political decision-making, and also in education. The Eurobarometer survey covers these three dimensions quite well:

a) Equality in the economic sphere: This dimension is represented in the Eurobarometer by the following item: "If jobs are scarce, women have as much right to do a job as men". Respondents could indicate on a four-point scale whether they "strongly agree", "tend to agree", "tend to disagree", or "strongly disagree" with the statement. We recoded the variable so that a higher score represents a strong agreement with the statement and therefore strong support for gender equality on the job market. A lower score represents a disagreement with the statement.

b) Equality in political decision-making: This dimension is captured in the Eurobarometer by an item which asks whether participants agree with the following statement: "On the whole, men make better political leaders than women". The four answers mentioned above were given to choose from, and higher scores represent strong support for women in politics.

c) Equality in education: The third dimension is measured by the following statement: "A university education is more important for a boy than for a girl". Again, participants were asked whether they "strongly agree", "tend to agree", "tend to disagree", or "strongly disagree" with the statement. High scores represent strong support for the statement and therefore the goal of gender equality in education.

5 Participants from former East and West Germany are still treated separately in the Eurobarometer. This separation seems reasonable to us, and we will adopt it in this article, because although both parts of Germany were re-unified in 1990 and share the same political and institutional framework, their values still differ (e.g. Meulemann 1996). 

and its support among citizens of 27 European countries

Table 1: Attitudes towards gender equality: means by country

\begin{tabular}{|c|c|c|c|c|c|}
\hline & $\begin{array}{l}\text { Equality in } \\
\text { the } \\
\text { Job Marketa }\end{array}$ & $\begin{array}{c}\text { Equality in } \\
\text { Political De- } \\
\text { cision- } \\
\text { Makinga } \\
\end{array}$ & $\begin{array}{l}\text { Equality in } \\
\text { Education }^{\text {a }}\end{array}$ & $\begin{array}{c}\text { Gender } \\
\text { Equality In- } \\
\text { dex }^{b}\end{array}$ & $\begin{array}{l}\text { Standard devia- } \\
\text { tion for Gender } \\
\text { Equality Index }\end{array}$ \\
\hline $\begin{array}{l}\text { EU-15 ("old" mem- } \\
\text { bers) }\end{array}$ & 3,483 & 3,069 & 3,393 & 9,971 & 1,907 \\
\hline Sweden & 3,761 & 3,499 & 3,753 & 11,038 & 1,380 \\
\hline Denmark & 3,772 & 3,418 & 3,776 & 10,979 & 1,417 \\
\hline the Netherlands & 3,639 & 3,204 & 3,733 & 10,587 & 1,604 \\
\hline Finland & 3,717 & 3,188 & 3,526 & 10,437 & 1,673 \\
\hline Spain & 3,534 & 3,312 & 3,483 & 10,372 & 1,972 \\
\hline France & 3,638 & 3,114 & 3,561 & 10,348 & 1,531 \\
\hline United Kingdom & 3,554 & 3,126 & 3,533 & 10,229 & 1,739 \\
\hline Belgium & 3,613 & 3,041 & 3,520 & 10,172 & 1,777 \\
\hline Luxembourg & 3,550 & 3,059 & 3,456 & 10,095 & 1,880 \\
\hline Germany (East) & 3,458 & 3,141 & 3,414 & 10,014 & 1,846 \\
\hline Ireland & 3,365 & 3,131 & 3,356 & 9,901 & 1,845 \\
\hline Germany (West) & 3,436 & 3,130 & 3,258 & 9,871 & 1,885 \\
\hline Northern Ireland & 3,561 & 2,937 & 3,320 & 9,842 & 1,677 \\
\hline Portugal & 3,578 & 2,796 & 3,382 & 9,769 & 1,850 \\
\hline Italy & 3,219 & 2,746 & 3,080 & 9,046 & 2,037 \\
\hline Greece & 3,021 & 2,717 & 3,150 & 8,899 & 2,054 \\
\hline Austria & 3,395 & 2,557 & 2,896 & 8,814 & 2,112 \\
\hline Accession I & 3,277 & 2,581 & 3,172 & 9,045 & 1,908 \\
\hline Malta & 3,462 & 3,149 & 3,493 & 10,108 & 1,740 \\
\hline Lithuania & 3,519 & 2,550 & 3,316 & 9,422 & 1,746 \\
\hline Cyprus & 3,328 & 2,608 & 3,375 & 9,336 & 1.946 \\
\hline Latvia & 3,476 & 2,646 & 3,206 & 9,333 & 1,813 \\
\hline Estonia & 3,447 & 2,544 & 3,316 & 9,290 & 1,672 \\
\hline Poland & 3,339 & 2,632 & 3,251 & 9,268 & 1,843 \\
\hline Slovenia & 2,937 & 2,722 & 3,468 & 9,125 & 1,882 \\
\hline Hungary & 3,461 & 2,543 & 2,976 & 8,972 & 2,015 \\
\hline Czech Republic & 3,032 & 2,480 & 3,164 & 8,672 & 1,902 \\
\hline Slovakia & 2,803 & 2,407 & 2,705 & 7,926 & 1,775 \\
\hline Accession II & 3,360 & 2,221 & 3,112 & 8,730 & 1,852 \\
\hline Bulgaria & 3,414 & 2,381 & 3,090 & 8,917 & 1,704 \\
\hline Romania & 3,340 & 2,167 & 3,120 & 8,667 & 1,972 \\
\hline Turkey & 3,375 & 2,239 & 2,570 & 8,169 & 2,378 \\
\hline
\end{tabular}

$\mathrm{a}=$ Answers could be given on a four-point scale reaching from 1 "strongly disagree" to 4 "strongly agree"

$\mathrm{b}=$ We have created an additive index out of the three questions, ranging from " 3 " for respondents who strongly disagree with the idea of equality in all three dimensions to " 12 " for respondents who strongly agree with all three items. 
The three questions have been used in other surveys as well (e.g., the 1999/2000 World Values Survey (WVS) and European Values Surveys (EVS) and the 1995/1996 WVS). It is notable that the first question concerning equality on the job market was changed in the Eurobarometer. Instead of asking whether participants agree with the statement "When jobs are scarce, men should have more right to a job than women", as was done in the WVS and EVS, the Eurobarometer asked whether "women have as much right to do a job as men". Not only was the succession of "women" and "men" reversed in the question, but the formulation "more right to a job" was changed to "as much right". This change in the wording may explain why the level of support for the idea of equality in the job market is much higher as compared to the results of two earlier studies (Gerhards/Hölscher 2005, Gerhards 2007).

In addition to analysing the three questions separately, we constructed an additive index made up of the three items (Cronbach's Alpha 0,535). This index measures general support for the idea of gender equality as envisaged by the EU. Table 1 shows the mean levels of support for each of the three dimensions as well as for the constructed index with countries sorted according to the length or status of their EU membership. The first group is made up of "old" EU member states, the second of the Southeastern European countries who joined the EU in 2004 (Enlargement I), the third of Bulgaria and Romania, who became members in 2007 (Enlargement II), and the fourth group consists of Turkey as the largest current candidate country.

When looking at the results, the first obvious finding is the strikingly high level of agreement in all countries. This is particularly true for equality between women and men on the job market. On this question, the respondents in every country in our analysis agree or strongly agree with the statement that women have "as much right" to do a job as men do, even when jobs are scarce. This may be interpreted as strong support for the EU's policy of equality between women and men the labour market, although the results may also partially be due to the specific formulation of the question (see above). Equality in political decision-making is the dimension for which the least support is shown, and only for this question do some countries reject the equality principle (i.e., the national mean is below 2,5). The majority of citizens in almost all of the analyzed countries, however, also support gender equality in this dimension.

The second interesting finding concerns the differences between country groups. As Table 1 shows, there are clear and significant differences between country groups regarding their general attitudes towards gender equality as measured by the equality index. Respondents in all countries support the concept of gender equality on average, but citizens in the "old" member states support gender equality most strongly. Support in Accession I and Accession II countries tends to be somewhat lower, and Turkish citizens show the lowest level of support for the EU's idea of gender equality.

Third, the results also reveal a rather high internal variance within particular aggregate country groups. Amongst "old" member states, Scandinavian countries and 
the Netherlands support gender equality close to the possible maximum, whereas southern countries like Italy, Greece, and Austria show significantly lower degrees of support. In the accession countries, Maltese citizens also support gender equality to an extent that exceeds several "old" member states and that deviates strongly from other Accession countries such as Slovakia.

Fourth, a high degree of variance is found not only between different countries, but also among citizens within some of the analyzed countries, as shown in the differing standard deviations. In countries such as Turkey, Austria, or Hungary, opinions differ more strongly than they do in Sweden or Denmark.

To summarize the descriptive findings: First, EU gender equality policy enjoys widespread support among EU citizens. The EU considers gender equality as an important issue in economic matters, in political decision-making, and in education; EU citizens generally support this understanding. This support is strongest in the "old" EU member states, decreases slightly for the Accession I countries, and declines even more so for the Accession II countries. Turkish citizens most clearly deviate from this principle, although also in Turkey, a majority still supports the idea of gender equality.

\section{Explaining citizens' attitudes towards gender equality}

The descriptive results in the previous section showed that there are substantial differences between countries and individuals in terms of attitudes towards gender equality. This section first discusses several explanatory factors that may influence attitudes towards gender equality and then tests empirically whether or not these factors have the expected effects. The explanatory factors can be divided into two groups: macro-variables that characterize entire countries and individual or microvariables that refer to characteristics of individual citizens. Appendix 1 gives a brief description of the variables.

We use two macro-factors as independent variables:

a) The first macro-variable considers that the European countries analyzed differ in their degree of economic modernization, which may affect their citizens' attitudes towards different aspects of social life. This assumption has a long history in socialscientific theory. ${ }^{6}$ Karl Marx was one of the first authors to assume a causal relationship between economic living conditions and peoples' values in the nineteenth century, and most modernization theories share this assumption. In this line of thought, the modernization process results in a one-time historical growth in the economy and the corresponding prosperity of citizens (Maddison 1995: 21). Regardless of how one

6 It would exceed the scope of this analysis to reconstruct modernization theory with all its facets, critics, and revisions. (for overviews see Berger 2000, Inglehart 2001, Knoebl 2003). 
explains this growth and developing societal prosperity, there exists substantial concurrence among various theorists that modernized societies can be described-not explained-by a set of characteristics that altogether form a syndrome (cf. Norris 2002: 20ff, Bell 1973). Important for our argument here is that most accounts of modernization theory converge on the assumption that as economic prosperity increases through modernization, a change in citizens' values occurs. According to Ronald Inglehart and his collaborators (Inglehart 1971, Inglehart 1997, Inglehart/Norris 2003, Inglehart/Welzel 2003, Inglehart/Welzel 2004, Welzel 2002), when chances to satisfy material needs increase, a shift takes place from materialist to post-materialist values or self-expression values as Inglehart has more recently called them. In other words, citizens' values shift from a materialist emphasis, which focuses on satisfying economic living conditions, security, national identity, and national exclusion towards post-materialist values, which can be characterized as the desire for self-fulfillment and participation, internationalism, tolerance, and the opening of national boundaries. Accordingly, we expect that citizens from economically less-developed countries will express less support for the idea that both genders should enjoy the same rights and opportunities in different societal spheres, while respondents from more economically modern countries will support gender equality. We used the Human Development Index (HDI), which is provided annually by the United Nations Development Program (e.g. UNDP 2007) to measure the degree of modernization in a country. The HDI includes three indices: real GNP per capita, average education levels, and average life expectancy. ${ }^{7}$

b) A second macro-factor that can be expected to influence attitudes toward gender equality is the level to which gender equality is politically institutionalized at the national level. Family and gender role models persist and are politically supported (Kaufmann et al. 1997) in the countries analysed. For example, socio-political measures in Scandinavian countries or in former East Germany supported the employment of women with small children, whereas women with children in former West Germany or in Italy were ideologically and structurally supported to stay at home (Wendt 1997, Wingen 1997). These family and gender models have led to different degrees of institutionalized gender equality in the past. We assume that the level of politically institutionalized gender equality influences citizens' attitudes towards gender equality. We hypothesize that citizens in countries with a high degree of established gender equality will show strong support for gender equality and vice versa. From the existing measurements of institutionalized gender equality, we chose to employ the annual "Gender Equality Index" (GEI) of the World Economic Forum (2007) that includes women's economic participation and opportunities (salaries, participation levels, access to highly-skilled employment), educational attainment (ac-

7 In addition to the HDI, the GDP at purchasing power parity (PPP) per-capita is an alternate way to measure the degree of economic modernization. We used both indicators in our analysis; they lead exactly to the same results. 
cess to and achievement in basic and higher level education), political empowerment (representation in decision-making structures), and "health and survival" information (life expectancy, sex ratio). The GEI includes more variables than other measures, such as the "Gender Empowerment Measure" of the UNDP, and therefore seems to be the best available measurement for our purpose. The GEI can range between 0 and 1, with high scores representing high levels of gender equality. The GEI is, however, only a very rough measurement of the differences between European countries in regard to gender equality policies and to the different political traditions of dealing with gender relations. ${ }^{8}$

In addition to the two macro-variables, we included four independent variables on the micro-level that may help explain attitudes towards gender equality.

c) The first independent variable on the individual level considers that people may follow their general ideological orientations when expressing support for gender equality. The left-right scheme depicts an abstract ideological grid that citizens use to interpret concrete political topics. Dieter Fuchs and Hans-Dieter Klingemann (1990) have empirically reconstructed the left-right scheme through an investigation of three countries. In their reconstruction, "right" is strongly associated with national identity, the conservation of the pre-existing system and status quo, as well as with exclusion. "Left" is associated with a general support of equality, solidarity, socialism, and internationalism. Accordingly, we can assume that citizens with a left-wing or leftist orientation likely support gender equality, whereas people on the right end of the spectrum are more likely to reject it. We used the following question to measure respondents' ideological orientation: "In political matters, people talk of 'the left' and 'the right'. How would you place your views on this scale ( $1=$ Left to $10=$ Right)?"

d) A second individual variable that may help to explain attitudes toward gender equality is the gender of the respondent. We assume that gender equality affects men and women differently insofar as women will be more likely benefit from gender equality policies. We hypothesize that women support the concept of gender equality more than men do.

e) The third individual variable that may influence attitudes toward gender equality is the respondent's level of education. Education may increase the likelihood of self-reflection and acquiring a scholarly worldview. Inglehart describes the effect associated with higher levels of education as "cognitive mobilization", in which education increases the likelihood that traditional concepts will be questioned and possibly rejected, rather than being automatically accepted (Inglehart 1990, cf. Dalton 1984).

8 Other relevant aspects of gender institutionalization suggested in the literature, but that cannot be taken up here due to missing comparative data, are the strength of domestic women's movements or certain "breadwinner models" that are furthered by national policies and welfare state measures (e.g. Korpi 2001, Pfau-Effinger 2004, Pfau-Effinger 2005) 
This questioning of tradition also relates to people's attitudes towards equality, tolerance, and non-discrimination in general, and in particular, towards gender equality. We therefore assume that respondents with a higher level of education support gender equality more strongly than do respondents with lower levels of education. The level of education is operationalized with the following question: "How old were you when you stopped full-time education?"

f) Finally, we assume that the religious orientation of the individual influences his or her attitude towards gender equality. For the purposes of this analysis, EU citizens have either no religious affiliation, are Muslim, Catholic, Protestant, or Orthodox Christian. ${ }^{9}$

1. All four religions have legitimized the dominance of men over women, albeit to varying degrees, at some point in time; some continue to do so. For example, the Bible's book of Genesis describes how, after the fall of man, the originally equal relation between man and woman transformed into a relationship in which woman became subject to man. The Koran states that men have superiority over women and provides the right to polygamy. We therefore assume that-notwithstanding which of these four denominations an individual belongs to-a higher degree of integration into a particular denomination will result in lower levels of support for gender equality. We measure the degree of integration into the different denominations with the question: "Apart from weddings or funerals, about how often do you attend religious services?"

2. We assume, however, that the four denominations have different effects on their followers' beliefs. It is therefore necessary to reconstruct gender roles as they are envisaged by the four religions. We tap into this controversial topic only briefly here (for more detail see Gerhards 2007). We rely on interpretations found in the literature, not judging the correctness of these interpretations, but using them only to formulate hypotheses which can then be tested empirically. According to the literature, Islam strongly advocates a traditional gender hierarchy, in which women are responsible for children and the household; men earn money and maintain a position of power in the relationship, and education and employment are subordinate for women (e.g. El-Saadawi 1991: 51, Nauck/Klaus 2005). In contrast, Christianity has comparatively little to say about gender roles (Mitterauer 1999: 325). We therefore expect that Muslims will support gender equality less strongly than will those in the Christian denominations. Of the latter three, Catholicism and Orthodox Christianity seem more strongly oriented towards traditional role models and less supportive of gender equality (for an example see Ratzinger/Amato 2004). Protestantism appears to deviate from the patriarchal gender order (Dülmen 1990: 157ff).

9 Several other religions were asked for in the survey, such as Hindu and Sikh. However, these religions are hardly represented in EU and candidate countries, and are therefore hardly present in the Eurobarometer. We therefore excluded these religious categorizations from our analysis. 
Our hypotheses include variables at the individual and country levels. To address this two-level data structure we test the hypotheses by estimating hierarchical linear regression models (cf. Snijders/Bosker 1999, Hans 2006), employing the HLM statistics software, version 6 (cf. Raudenbush et al. 2004). The procedure used is the restricted maximum likelihood estimation.

The two-level analysis is performed in four steps. ${ }^{10}$ We start with the estimation of the empty model with the random intercept only. From the empty model, the intraclass correlation coefficient-the variance component attributed to the differences between the countries-is then computed. In Model 1, all variables at the individual level are added into the analysis to test whether left-right-orientation, gender, education and religious orientation have a significant impact on support for gender equality. Model 2 includes the two macro-variables HDI and the Gender Equality Index. We then test whether the impact of the individual level variables is fixed or whether it varies across countries. After calculating separate regressions for each country, we found that the impact of left-right placement, gender, education, and church attendance vary across countries. We then estimated Model 3 by using all variables at the individual and country levels, allowing the effects of the four variables to vary at the country level. The log-likelihood statistic and the Maddala $\mathrm{R}^{2}$ for each model are also computed. A large deviance-difference between two models indicates an increased fit of the model; in general, the smaller the deviance, the better the model's fit.

Table 2 contains the results of the hierarchical regression analysis. Variance components, deviance, and the Maddala $\mathrm{R}^{2}$ results are reported at the bottom of the table.

10 In order to compute the Maddala $\mathrm{R}^{2}$ for both levels combined, an empty model without random intercept was estimated as well. 
Table 2: $\quad$ Multilevel analysis of attitudes towards gender equality

\begin{tabular}{|c|c|c|c|c|}
\hline & $\begin{array}{l}\text { Empty } \\
\text { Model }\end{array}$ & Model 1 & Model 2 & Model 3 \\
\hline Intercept & $9,546^{* * *}$ & $9,614^{* * *}$ & $9,631^{* * *}$ & $9,652^{* * *}$ \\
\hline \multicolumn{5}{|l|}{ Level-1 Variables } \\
\hline Left-Right & & $-0,045^{* * *}$ & $-0,044^{* * *}$ & $-0,046^{* * *}$ \\
\hline Gender & & $-0,639^{* * *}$ & $-0,638^{* * *}$ & $-0,640^{* * *}$ \\
\hline Education & & $0,335^{* * *}$ & $0,332^{* * *}$ & $0,325^{* * *}$ \\
\hline Church attendance & & $-0,065^{* * *}$ & $-0,064^{* * *}$ & $-0,056^{* *}$ \\
\hline Protestant & & $-0,402^{* * *}$ & $-0,406^{* * *}$ & $-0,425^{* * *}$ \\
\hline Roman Catholic & & $-0,275^{* * *}$ & $-0,275^{* * *}$ & $-0,312^{* * *}$ \\
\hline Orthodox Christian & & $-0,666^{* * *}$ & $-0,625^{* *}$ & $-0,548^{* * *}$ \\
\hline Muslim & & $-0,795^{* * *}$ & $-0,529^{* * *}$ & $-0,567^{* * *}$ \\
\hline \multicolumn{5}{|l|}{ Level-2 Variables } \\
\hline HDI & & & 4,392 & $4,076^{* * *}$ \\
\hline GEI & & & 4,771 & $3,965^{* * *}$ \\
\hline \multicolumn{5}{|l|}{ Variance components } \\
\hline Level-2 Variance & $0,690^{* * *}$ & $0,332^{* * *}$ & $0,150^{* * *}$ & $0,153^{* * *}$ \\
\hline Random Effect Left-Right & & & & $0,002^{* * *}$ \\
\hline Random Effect Gender & & & & $0,055^{* * *}$ \\
\hline Random Effect Education & & & & $0,008^{*}$ \\
\hline Random Effect Church Attendance & & & & $0,002^{* * *}$ \\
\hline Level-1 Variance & 3,561 & 3,344 & 3,344 & 3,309 \\
\hline Intraclass Correlation & $16,2 \%$ & & & \\
\hline Deviance & 70412,553 & 69353,092 & 69322,529 & 69209,323 \\
\hline Maddala $\mathbf{R}^{2}$ & 0,150 & 0,201 & 0,203 & 0,208 \\
\hline
\end{tabular}

Unstandardized regression coefficents are reported. $\mathrm{N}_{1}=17107 ; \mathrm{N}_{2}=30 .{ }^{*} \mathrm{p}<.05 ;{ }^{* *} \mathrm{p}<.01 ;{ }^{* * *} \mathrm{p}<.001$ (two-tailed tests). Weighting: Variables at the individual level are weighted by socio demographic factors. Contextual level variables are weighted by the country group weight EU25 + 4CC.

The results of the empty model show that the probability of supporting the principle of gender equality varies significantly by country. The intraclass correlation coefficient is about 0,162 , indicating that $16 \%$ of the variance can be attributed to the differences between countries. Adding the variables at the individual level leads to an improvement in the empty model as shown in Model $1 .{ }^{11}$ All coefficients go in the expected direction and are significant at the 0.1 percent level. Citizens with a left-wing orientation support gender equality, whereas people on the right end of the spectrum are

11 Devianceем-Devianceм1 $=1059.461, \mathrm{P}<0.01$ 
more likely to reject it. Women support gender equality more than men. Respondents with higher education levels are also more likely to support the idea of gender equality. It is also evident that membership in a religious denominations and the degree of integration into a particular religious institution has a negative influence on support for gender equality. Affiliation with the Roman Catholic Church, somewhat surprisingly, has the smallest negative impact, while Muslims, as expected, reject gender equality the strongest.

Adding the country level variables improves the fit of our calculation (Model 2 as compared to Model 1). ${ }^{12}$ The effects of the HDI and the Gender Equality Index correspond to our expectations: The level of modernization and the degree of institutionalized gender equality both increase the likelihood that citizens support gender equality. The inclusion of the HDI in Model 2 decreases the level of rejection of gender equality by Muslims. That mirrors the fact that Turkey is the only country with a very high share of Islamic respondents and at the same time the country with the lowest HDI-level.

Model 3 specifies the impact of the left-right orientation, gender, education, and church attendance by allowing their effects to vary over countries. All random effects are significant, which means that the effects of these variables are actually country specific. This is in line with the results of our previously calculated separate regressions. ${ }^{13}$ Whereas the effects of gender and education vary over country only in their level of support for gender equality, the effects of the left-right orientation and church attendance vary in their level and in their direction. Women and comparatively highly educated persons are more likely to support gender equality than are men and respondents with lower levels of education. In most countries, frequently attending church decreases the probability of supporting the principle of gender equality, while at the same time frequent churchgoers in other countries are more likely to support gender equality. The same is true for the left-right orientation; while in most countries left-leaning citizens support the idea of gender equality more strongly, there are some countries where citizens with a right-leaning orientation are more likely to support gender equality.

Adding these random effects lead to another significant improvement in the model. ${ }^{14}$ Model 3 has the best fit with an explained variance (computed by Maddala $\mathrm{R}^{2}$ ) of $21 \%$. We can thus satisfactorily explain citizens' attitudes towards gender equality with our independent variables. This holds especially true at the country

12 Deviance м1-Difference $22=30.563, \mathrm{P}<0.01$

13 It can be calculated that 95 percent of the effects of Left-Right Orientation have a coefficient between $-0.128(-0.045-2 * \sqrt{0} .002)$ and $+0.038(-0.045+2 * \sqrt{ } 0.002)$. The coefficients of gender are between $1.110(-0,638-2 * \sqrt{0} 0.055)$ and $-0.170(-0,638+2 * \sqrt{0} .055)$; those of education are between $0.143(0,325-$ $2 * \sqrt{0.008)}$ and $0.507(0,325+2 * \sqrt{0} .008)$. The coefficients of church attendance vary over the countries between $-0.156(-0,056-2 * \sqrt{ } 0.002)$ and $0.043(-0,056+2 * \sqrt{ } 0.002)$.

14 Deviance м2-Difference $\mathrm{M}_{3}=113.297, \mathrm{P}<0.01$ 
level, for which we can explain $78 \%$ of the variance (level-2 $\mathrm{R}^{2} \mathrm{Bryk}_{\text {and Raudenbush), as }}$ compared to only $7 \%$ at the individual level (level-1 $\mathrm{R}^{2}$ Bryk and Raudenbush).

\section{Summary}

The European Union and its institutions can be understood as "value entrepreneurs" that have developed definite ideas of how European society should look. These conceptions of the ideal European society include ideas about gender relations. The EU's policy on gender relations revolves around the core theme of gender equality. Equality between men and women in the workplace and in the economic realm is seen as the most important issue; however, the EU's approach toward gender equality has broadened in recent years. The current understanding includes the participation of women in decision-making and political positions as well as equality in education.

We have analyzed whether citizens of EU member states and Turkey support the principle of gender equality. Analyzing data taken from the Eurobarometer survey, we could show that the idea of gender equality is rather strongly supported in the 27 countries analyzed. Equality between women and men on the job market, concerning participation in political decision-making, and in respect to university education are supported or even strongly supported throughout Europe. Compared to the results of earlier studies, in which we analyzed data from 1994 and 2000 (Gerhards/Hölscher 2005, Gerhards 2007), the overall level of support for the idea of gender equality has become much higher. This change may indicate a real change in citizens' attitudes or may be a result of differences in how the survey questions were formulated (especially the question on women in the labour market-see above). Our data did not allow us to conclude which one of these interpretations was correct.

As we found in our earlier studies, levels of support vary between country groups and individual countries. Support is strongest among citizens of the "old" EU member states, decreases for recent Accession countries, and even more so for Turkey. Scandinavian countries and the Netherlands support gender equality close to the possible maximum, whereas Turkey and Slovakia show significantly lower degrees of support.

Using a multi-level analysis, we tried to account for the differences in support for gender equality between countries. On the macro-level support for gender equality is influenced by the country's degree of modernization and the extent to which gender equality is nationally institutionalized. Additionally, the individual respondent's political-ideological orientation, gender, level of education, religious affiliation, and integration into his or her religious institution influenced his or her support for gender equality.

In classifying countries with the two macro categories, we have not done justice to the particular historical developments of individual countries. Comparative social scientists stress the importance of historical, path-dependent developments of individual 
countries (e.g. Pfau-Effinger 2004, Pfau-Effinger 2005). These scholars criticize approaches that treat countries as a complex of variables. We agree with this critique, but believe that both methodologies are compatible. Analyses such as ours can develop a rough sketch of the differences between countries and cultures but cannot replace a historical approach of the particular conditions in a country. This study did not take developmental, historical paths of individual societies into account. Consequently, the explanatory power of our findings is limited. Despite this shortcoming, however, we are able to explain citizens' value orientations relatively well with our chosen factors.

\section{References}

Bell, D., 1973: The coming of post-industrial society: A venture of social forecasting. New York: Basic Books.

Berger, J., 2000: Modernization Theory and Economic Growth. S. 31-47 in: W. Schelkle / W.-H. Krauth / M. Kohli / G. Elwert (Hrsg.): Paradigms of Social Change: Modernization, Development, Transformation, Evolution. Frankfurt a.M. \& New York: Campus \& St. Martin's Press.

Bergmann, K., 1999: Die Gleichstellung von Frauen und Männern in der europäischen Arbeitswelt. Eine rechtsvergleichende, empirisch-politikwissenschaftliche Untersuchung. Opladen: Westdeutscher Verlag.

Council of the European Union, 1985: Resolution (...) containing an action programme on equal opportunities for girls and boys in education. S. 197-200 in: European Commission (Hrsg.): Equality for Women and Men. European Community Acts. Luxembourg: Office for Official Publications of the European Communities.

Council of the European Union, 2001: Council resolution (...) on science and society and on women in science, Official Journal of the European Communities C199: 1-2.

Council of the European Union, 2003: Council resolution (...) on equal access to and participation of women and men in the knowledge society for growth and innovation, Official Journal of the European Communities C317: 6-8.

Daley, C. / M. Nolan (Hrsg.), 1994: Suffrage and Beyond: International Feminist Perspective. Auckland: Auckland University Press.

Dalton, R.J., 1984: Cognitive Mobilization and Partisan Dealignment in Advanced Industrial Democracies, Journal of Politics 46: 264-284.

Dülmen, R.v., 1990: Kultur und Alltag in der Frühen Neuzeit. Bd. 1: Das Haus und seine Menschen. München: C.H. Beck.

El-Saadawi, N., 1991: Tschador. Frauen im Islam. Bremen: Con.

European Commission, 1994: European Social Policy. Luxembourg: Office for Official Publications of the European Communities.

European Commission, 2000: Commission decision (...) relating to gender balance within the committees and expert groups established by it, Official Journal of the European Communities L154: 3435.

European Commission, 2006a: Equality for Women and Men. European Community Acts. Luxembourg: Office for Official Publications of the European Communities.

European Commission, 2006b: A Roadmap for equality between women and men 2006-2010. Luxembourg: Office for Official Publications of the European Communities.

European Union, 1957: Treaties of Rome. Rome: EU.

European Union, 2000: Charter of Fundamental Rights of the European Union, Official Journal of the European Communities C364: 1-22. 
European Union, 2007: Treaty of Lisbon amending the Treaty on European Union and the Treaty establishing the European Community. Lissabon: EU.

Fuchs, D. / H.-D. Klingemann, 1990: The Left-Right Schema. S. 203-234 in: M.K. Jennings / J.W. van Deth / S.H. Barnes / D. Fuchs / F.J. Heunks / H.-D. Klingemann / J.J.A. Thomassen (Hrsg.): Continuities in Political Action: A Longitudinal Study of Political Orientations in Three Western Democracies. Berlin \& New York: de Gruyter.

Gerhards, J., 2007: Cultural Overstretch? Differences Between Old and New Member States of the EU and Turkey. London: Routledge.

Gerhards, J. / M. Hölscher, 2003: Kulturelle Unterschiede zwischen Mitglieds- und Beitrittsländern der EU. Das Beispiel Familien- und Gleichberechtigungsvorstellungen, Zeitschrift für Soziologie 32: 206-225.

Gerhards, J. / M. Hölscher, 2005: Kulturelle Unterschiede in der Europäischen Union. Ein Vergleich zwischen Mitgliedsländern, Beitrittskandidaten und der Türkei. Wiesbaden: Verlag für Sozialwissenschaften.

Gerhards, J. / H. Lengfeld, 2006: Das Ökologieskript der Europäischen Union und seine Akzeptanz in den Mitglieds- und Beitrittsländern der EU, Zeitschrift für Soziologie 35: 24-40.

Hans, S., 2006: Die Analyse gepoolter Daten mit Mehrebenenmodellen. Einstellungen zu Zuwanderern im europäischen Vergleich. Freie Universität Berlin, Institut für Soziologie: Berliner Studien zur Soziologie Europas Nr. 6.

Hölscher, M., 2006: Wirtschaftskulturen in der erweiterten EU. Die Einstellungen der Bürgerinnen und Bürger im europäischen Vergleich. Wiesbaden: Verlag für Sozialwissenschaften.

Inglehart, R., 1971: The Silent Revolution in Europe, American Political Science Review 65: 991-1017.

Inglehart, R., 1990: Cultural Shift in Advanced Industrial Society. Princeton: Princeton University Press.

Inglehart, R., 1997: Modernization and Postmodernization. Cultural, Economic and Political Change in 43 Societies. Princeton: Princeton University Press.

Inglehart, R., 2001: Sociological Theories of Modernization. S. 9965-9971 in: N.J. Smelser / P.B. Baltes (Hrsg.): International Encyclopedia of the Social and Behavioral Sciences. Amsterdam: Elsevier.

Inglehart, R. / P. Norris, 2003: Rising Tide. Gender Equality and Cultural Change around the World. Cambridge: Cambridge University Press.

Inglehart, R. / C. Welzel, 2003: Political Culture and Democracy: Analyzing Cross-Level Linkages, Comparative Politics 36: 61-81.

Inglehart, R. / C. Welzel, 2004: Modernization, Cultural Change and Democracy. The Human Development Sequence. Cambridge: Cambridge University Press.

Kaufmann, F.-X. / A. Kuijsten / H.-J. Schulze / K.P. Strohmeiner (Hrsg.), 1997: Family Life and Family Policies in Europe. Oxford: Clarendon.

Knoebl, W., 2003: Theories that Won't Pass Away: The Never Ending Story of Modernization Theory. S. pp. 96-107 in: G.D.u.E.F. Isin (Hrsg.): Handbook of Historical Sociology. London: Sage.

Korpi, W., 2001: Class, Gender and Inequality: The Role of the Welfare State. S. 52-72 in: M. Kohli / M. Novak (Hrsg.): Will Europe Work? Integration, Employment and the Social Order. London \& New York: Routledge.

Läufer, T. (Hrsg.), 1999: Vertrag von Amsterdam. Texte des EU-Vertrages und des EG-Vertrages mit den deutschen Begleittexten. Bonn: Europa Union Verlag.

Maddison, A., 1995: Monitoring the World Economy 1820-1992. S. Paris: Development Centre of the Organisation for Economic Co-operation and Development.

Meulemann, H., 1996: Werte und Wertewandel. Zur Identität einer geteilten und wieder vereinten Nation. Weinheim, München: Juventa.

Meyer, J.W. / J. Boli / G. Thomas / F.O. Ramirez, 1997: World Society and the Nation State, American Journal of Sociology 103: 144-181. 
Mitterauer, M., 1999: Europäische Familienformen im interkulturellen Vergleich. S. 313-332 in: W. Köpke / B. Schmelz (Hrsg.): Das Gemeinsame Haus Europa. München: Deutscher Taschenbuch Verlag.

Nauck, B. / D. Klaus, 2005: Families in Turkey. S. 364-388 in: B.N. Adams / J. Trost (Hrsg.): Handbook of World Families. London: Sage.

Norris, P., 2002: Democratic Phoenix. Cambridge: Cambridge University Press.

Ostner, I., 1992: Geschlechterverhältnisse im Prozeß der europäischen Integration. S. 818-826 in: B. Schäfers (Hrsg.): Lebensverhältnisse und soziale Konflikte im neuen Europa. Verhandlungen des 26. Deutschen Soziologentages in Düsseldorf 1992. Frankfurt: Campus.

Ostner, I. / J. Lewis, 1998: Geschlechterpolitik zwischen europäischer und nationalstaatlicher Regelung. S. 196-239 in: S. Leibfried / P. Pierson (Hrsg.): Standort Europa. Sozialpolitik zwischen Nationalstaat und europäischer Integration. Frankfurt a.M.: Suhrkamp.

Page, B.I. / R.Y. Shapiro, 1983: Effects of Public Opinion on Policy, American Political Science Review 77: 175-190.

Pfau-Effinger, B., 2004: Historical paths of the male breadwinner family model - explanation for crossnational differences, British Journal of Sociology 55: 377-399.

Pfau-Effinger, B., 2005: Welfare State Policies and the Development of Care Arrangements, European Societies 7: 321-347.

Ramirez, F.O. / Y. Soysal / S. Shanahan, 1997: The Changing Logic of Political Citizenship: CrossNational Acquisition of Women's Suffrage Rights, 1890 to 1990, American Sociological Review 62: 735-745.

Ratzinger, J. / A. Amato, 2004: Schreiben an die Bischöfe der katholischen Kirche über die Zusammenarbeit von Mann und Frau in der Kirche und in der Welt.

Raudenbush, S.W. / A.S. Bryk / Y.F. Cheong / R. Congdon, 2004: HLM 6 - Hierarchical Linear and Nonlinear Modeling. Lincolnwood: Scientific Software International.

Schmidt, V., 2005: Gender Mainstreaming - an Innovation in Europe? The Institutionalisation of Gender Mainstreaming in the European Commission. Opladen: Barbara Budrich.

Schunter-Kleemann, S., 1992: Europas Frauen gleichberechtigt ? Die Politik der EG-Länder zur Gleichberechtigung im Arbeitsleben. S. 25-49 in: R. Bauer (Hrsg.): Sozialpolitik in deutscher und europäischer Sicht. Rolle und Zukunft der Freien Wohlfahrtspflege zwischen EG-Binnenmarkt und Beitrittsländern. Weinheim.

Snijders, T. / R. Bosker, 1999: Multilevel Analysis: An introduction to basic and advanced multilevel modeling. London: Sage.

UNDP, 2007: Human Development Report 2007. New York: United Nations Development Programme.

Watson, P., 2000: Politics, Policy and Identity: EU Eastern Enlargement and East-West Differences., Journal of European Public Policy 7: 369-384.

Welzel, C., 2002: Fluchtpunkt Humanentwicklung. Über die Grundlagen der Demokratie und die Ursachen ihrer Ausbreitung. Wiesbaden: Westdeutscher Verlag.

Wendt, H., 1997: The Former German Democratic Republic: the Standardized Family. S. 114-154 in: F.X. Kaufmann / A. Kuijsten / H.-J. Schulze / K.P. Strohmeiner (Hrsg.): Family Life and Family Policies in Europe. Oxford: Clarendon.

Wessels, W., 1997: An Ever Closer Fusion? A Dynamic Macropolitical View on Integration Processes, Journal of Common Market Studies 35: 267-299.

Wingen, M., 1997: Familienpolitik. Grundlagen und aktuelle Probleme. Bonn: Bundeszentrale für politische Bildung.

Wobbe, T., 2001: Institutionalisierung von Gleichberechtigungsnormen im supranationalen Kontext: Die EU-Geschlechterpolitik. S. 332-355 in: B. Heintz (Hrsg.): Geschlechtersoziologie. Opladen: Westdeutscher Verlag. 
Wobbe, T. / I. Biermann, 2007: Die Metamorphosen der Gleichheit in der Europäischen Union. Genese und Institutionalisierung supranationaler Gleichberechtigungsnormen, Kölner Zeitschrift für Soziologie und Sozialpsychologie 59: 565-588.

World Economic Forum, 2007: The Global Gender Gap Report 2007.

\section{Appendix 1: Description of variables}

\begin{tabular}{|c|c|c|c|}
\hline Variable & Range & Description & Data-source \\
\hline $\begin{array}{l}\text { Attitudes to- } \\
\text { wards political } \\
\text { gender equality }\end{array}$ & & $\begin{array}{l}\text { "On the whole, men make better political } \\
\text { leaders than women: } 1=\text { strongly agree, } 2= \\
\text { tend to agree, } 3=\text { tend to disagree, } 4= \\
\text { strongly disagree, } 5=\mathrm{dk} . " \\
\text { Operationalization: Category } 5 \text { was recoded as } \\
\text { missing. }\end{array}$ & EB 63.1 \\
\hline $\begin{array}{lr}\text { Attitudes } & \text { to- } \\
\text { wards } & \text { labour } \\
\text { market } & \text { gender } \\
\text { equality } & \end{array}$ & 1,4 & $\begin{array}{l}\text { "If jobs are scarce, women have as much } \\
\text { right to a job as men: } 1=\text { strongly agree, } 2= \\
\text { tend to agree, } 3=\text { tend to disagree, } 4= \\
\text { strongly disagree, } 5=\mathrm{dk} . " \\
\text { Operationalization: recoded: } 1=\text { strongly dis- } \\
\text { agree, } 2=\text { tend to disagree, } 3=\text { tend to agree, } \\
4=\text { strongly agree \& Category } 5 \text { was recoded } \\
\text { as missing. }\end{array}$ & EB 63.1 \\
\hline $\begin{array}{lr}\text { Attitudes } & \text { to- } \\
\text { wards } & \text { educa- } \\
\text { tional } & \text { gender } \\
\text { equality } & \end{array}$ & 1,4 & $\begin{array}{l}\text { "A university education is more important } \\
\text { for a boy than for a girl: } 1=\text { strongly agree, } 2 \\
=\text { tend to agree, } 3=\text { tend to disagree, } 4= \\
\text { strongly disagree, } 5=\mathrm{dk} . " \\
\text { Operationalization: Category } 5 \text { was recoded as } \\
\text { missing. }\end{array}$ & EB 63.1 \\
\hline $\begin{array}{l}\text { Index }- \text { Support } \\
\text { for gender } \\
\text { Equality }\end{array}$ & 3,12 & $\begin{array}{l}\text { Operationalization: addition of all three di- } \\
\text { mensions for gender equality: } 3=\text { no support } \\
\text { for gender equality ... } \\
12 \text { = full support for gender equality. }\end{array}$ & Recoded EB 63.1 \\
\hline $\begin{array}{l}\text { Left-Right- } \\
\text { Orientation }\end{array}$ & 1,10 & $\begin{array}{l}\text { "In political matters people talk of "the left" } \\
\text { and "the right". How would you place your } \\
\text { views on this scale: } \\
1=\text { left ... } 10=\text { right, } 11=\text { refusal, } 12=\mathrm{dk} \text { ?" } \\
\text { Operationalization: Category } 11 \text { and } 12 \text { were } \\
\text { recoded as missing. }\end{array}$ & EB 63.1 \\
\hline Gender & 0,1 & $\begin{array}{l}1=\text { male, } 2=\text { female } \\
\text { Operationalization: recoded } 0=\text { female, } 1= \\
\text { male. }\end{array}$ & EB 63.1 \\
\hline Education & 1,5 & $\begin{array}{l}\text { "How old were you when you stopped full- } \\
\text { time education". } \\
\text { Operationalization: recoded } 1=\text { no fulltime } \\
\text { education, } 2=15,3=16-19,4=20-24,5= \\
\text { over } 25 \text { \& Category } 6 \text { was recoded as missing }\end{array}$ & EB 63.1 \\
\hline $\begin{array}{l}\text { Church Atten- } \\
\text { dance }\end{array}$ & 1,8 & $\begin{array}{l}\text { "Apart from weddings and funerals, about } \\
\text { how often do you attend religious services: } \\
1=\text { more than once a week, } 2=\text { once a week, } 3\end{array}$ & EB 63.1 \\
\hline
\end{tabular}


$=$ about once a month, $4=$ About each two or three month, $5=$ only on special holidays, $6=$ about once a year, $7=$ less often, $8=$ never, $9=$ dk?"

Operationalization: recoded: $1=$ never $\ldots 8=$ more than once a week \& : Category 9 was recoded as missing.

\begin{tabular}{|c|c|c|}
\hline $\begin{array}{l}\text { Protestant/ } \\
\text { Roman Catholicl } \\
\text { Orthodox/ } \\
\text { Muslim }\end{array}$ & 0,1 & $\begin{array}{l}\text { "Do you consider yourself to be...: } 1 \text { = Catho- EB } 63.1 \\
\text { lic, } 2=\text { Orthodox, } 3=\text { Protestant, } 4=\text { Other } \\
\text { Christian, } 5=\text { Jewish, } 6=\text { Muslim, } 7=\text { Sikh, } 8 \\
\text { = Buddhist, } 9=\text { Hindu, } 10=\text { Atheist, } 11=\text { Non } \\
\text { believer/ Agnostic, } 12=\text { Other, } 13=\text { dk." } \\
\text { Operationalization: recoded: dummy variables } \\
\text { with reference group = } 10+11 \text { \& Category } 4, \\
\text { 5, 7,8,9,12 \& } 13 \text { was recoded as missing }\end{array}$ \\
\hline HDI & $\begin{array}{l}0.742, \\
0.941\end{array}$ & $\begin{array}{l}\text { The HDI includes three indices: real GNP per United Nations Devel- } \\
\text { capita, the average level of education, and opment Program } \\
\text { average life expectancy. }\end{array}$ \\
\hline $\begin{array}{l}\text { Gender Equality } \\
\text { Index }\end{array}$ & $\begin{array}{l}0.5850 \\
0.8133\end{array}$ & $\begin{array}{l}\text { GEI includes women's economic participa- World Economic Fo- } \\
\text { tion and opportunities, educational achieve- rum } \\
\text { ment, political empowerment, and "health } \\
\text { and survival" information. } \\
0=\text { no equality ... } 1 \text { = full equality }\end{array}$ \\
\hline
\end{tabular}

